\title{
The Washback Effects of the TOEIC Examination on the Teachers and Students of a Thai Business School
}

\author{
PEERASAK APICHATROJANAKUL \\ Shinawatra International University, Thailand
}

\begin{abstract}
Bio Data:
Peerasak Apichatrojanakul worked at Sukhothai Business School in Bangkok, Thailand, as the head of Foreign Language Department for 4 years. Currently, he is an English instructor of School of Liberal Arts and Language Center at Shinawatra International University, Bangkok, Thailand.
\end{abstract}

\begin{abstract}
This paper looks at some washbacks of the TOEIC examination on the teachers and students through his own teaching experience with TOEIC preparation courses and interview results from those of a Bangkok's business school.
\end{abstract}

\section{Introduction}

Most teachers teaching English in Thailand are not well aware of the washback effects of the courses they are teaching. Of course, a lot of them who have many years of teaching experience must have experienced or seen it to a certain extent in their careers. Similarly, on the part of students studying English, most of them must have experienced some kind of washback in some of the courses that they have passed. However, most of them are not aware of it, too. In order for these teachers and learners to know and understand what washback is like, there is an effort in this essay to study the definitions of washback as well as the significance of washback effects, both positive and negative, of the TOEIC Examination on general Thai teachers and students, as exemplified by those of a Bangkok's business school. In- 
depth one to one interviews of some of the TOEIC teachers and learners of that institution are also included in this present study.

\section{Definitions of Washback and its Significance}

One good definition of washback (or sometimes known as 'backwash') which was proposed by Alderson (1996), is the influence that writers on language testing, syllabus design, and language teaching believe a test will have on the teaching that precedes it. Similarly, washback can be broadly defined as the effect of a test on teaching and often also on learning, and it has been variously associated with effects on teachers and learners (Green, 2007). In recent decades, the significance of washback effects in the world of teaching English seems to have increased, as evidenced by the availability of many English proficiency preparation courses and books, including TOEIC (Testing of English for International Communication), on the education market. Here in Bangkok, Thailand, the washback effects of TOEIC on teachers and learners can be seen in the many language centers and general institutions which offer TOEIC preparation courses, such as the Bright Brain, Recovery Language School, EF English First, and Wall Street English. In addition, the washback effects of TOEIC can be seen in private tutoring classes on TOEIC which are being heavily advertized on websites, like www.dek-d.com or www.Vchar karn.com. Sukhothai Business School in Bangkok, at which I have been teaching since 2006, became the first and only business and large-scale vocational school (with more than 2,000 all female students and 100 teachers in total) that included TOEIC preparation courses as extra-curricular in the year 2006. That was because the school had earlier learned that there was a high demand for new 
graduates having a good TOEIC score by the workforce market and believed that a score of the test had a very high practicality and validity due to its many kinds of well-designed multiple-choice questions (Nall, 2003).

\section{My Own Experience about Washback of TOEIC}

In the first year of my teaching the TOEIC courses at Sukhothai, the school deemed it necessary to apply the concept of 4-mat model (similar to the PPP Approach) into teaching such courses to the 1st year nursing and English-major students totaling approximately 500. The model emphasized a rotation between left and right-brain activities also gives prime time to the basically different orientations and should lead to whole-brain performance (Scott, 1994). As a result, the syllabus design, study sheets, and lesson plans were full of communicative activities (like pair work, group work, and presentations) and grammar exercises and quizzes, rather than sample TOEIC questions. In other words, the materials and teaching techniques at that time were not quite appropriate for preparing the students to tackle the real TOEIC examination. On the part of the learners (both English and nursing major students), most of them could not reach the minimum required scores of 150 and 200 at the end of the academic year (Minimum required scores are higher in the next academic years.). Apparently, in that year there was not so much washback on the teachers and learners, for the TOEIC Examination and the teaching/learning styles and materials did not match.

However, in the second year the washback effects of TOEIC were more evident, since the school decided to stop using the student-centered style for teaching TOEIC and adopt the teacher-centered teaching style. Additionally, the 
studysheets contained 6 units incorporating grammar points which the students would encounter in the real TOEIC examination, and each unit was comprised of sample TOEIC questions from the 7 parts of TOEIC examination, namely Picture Description, Questions \& Responses, Short Conversation, Shot Talk, Incomplete Sentences, Error Recognition, and Reading Comprehension. Consequently, in this second year there were quite a lot of washback effects, both positive and negative ones, in the new teaching system, because the TOEIC Examination had a great impact on the school in designing the syllabus and on the TOEIC teachers in choosing the materials, creating the studysheets, and adopting new teaching techniques.

One of the positive washback effects found in my second year was that the teacher could ensure that most of the students will get a better score in the test than before by using some kind of grammar translation teaching style as a score booster. That is probably because with the new teaching system the students will be more exposed to real TOEIC questions through different forms of TOEIC practices by using the techniques similar to those of the Grammar Translation, such as reading comprehension questions, fill-in-the-blanks, and synonyms \& antonyms (LarsenFreeman, 2000). Another positive effect was that the teacher could teach the students the skills for taking the examination directly, without spending a lot of time on explaining certain grammatical structures and other unnecessary issues. Nevertheless, one disadvantage of washback of TOEIC was that students did not have much time to discuss with their friends because of the time constraint or a loss of instructional time. Another disadvantage was that the students had little chance to 
practice their writing and speaking and even their thinking or problem-solving skills in the classroom, when compared to their first year of studying TOEIC (Robb \& Ercanbrack, 1999). Furthermore, the students seemed to be very anxious and stressed out, especially when the examination day was coming closer.

In order to probe more washback effects of the TOEIC examination on the teachers, I decided to interview some of the school's TOEIC teachers who have so far taught TOEIC courses at the school for a number of courses. In interviewing these teachers, the interview form comprising 13 questions was used to gain opinions about the positive and negative effects of TOEIC on the teachers' teaching strategies and suggestions on their TOEIC preparation courses that they have been teaching. The one-to-one interviews were conducted at Sukhothai Business School, and each of the interviews lasted approximately 30 minutes.

\section{Interviews of Teachers to Find Washback Effects}

The first teacher whom I had an interview with was Ajarn Supannee (or teacher Supannee), who has been teaching for 3 courses so far. According to this teacher, one of the most outstanding benefits of the TOEIC preparation courses for both the certificate and the diploma levels with the new teaching style (teacher-centered with grammar translation) was that students can have a chance to be exposed to a lot of questions emphasizing on grammar points as well as a wide range of vocabulary which students tend to experience in the reading part of the real TOEIC examination that they will take at the end of the academic year. As a result, similar to what Robb and Ercanbrack (1999) concluded in A Study of the Effect of Direct Test Preparation on the TOEIC Scores of Japanese University students, the scores of the reading component 
of the students at Sukhothai Business School tend to be higher, when compared to their performances in the first year. In addition, with the use of the grammar translation approach, explanations of grammatical points in the class can be made more easily and quickly, since there are not a lot of group activities requiring much discussion and interaction between the students themselves. However, some negative points of such courses that she found were that students sometimes got bored with a series of difficult questions having different grammar points. At this point, she further gave a good example that the first 10 questions of Part 1 and Part 2 could contain a concentration of tenses, gerunds, participles, or auxiliary verbs; as a result, the teacher has to try hard in covering all of these grammar points with the limitation of class time, as evidenced by her tight lesson plans. At this point, the teacher could sometimes make the students perplexed, bored, pressured and even discouraged, without proper instructions and explanations by the teacher. Another disadvantage or negative washback effect of TOEIC on the teacher that she found was that the studysheets were divided into 6 units - each of which concentrating on a particular grammar point, such as infinitives, prepositions, or synonyms \& antonyms. She further explained, "this arrangement is not realistic and rather inconsistent, because in a real TOEIC test the questions are not categorized in terms of grammar points, and the test is not divided into 6 units!" At the end of interview, she made a prediction that in the near future other business schools in Thailand will surely have TOEIC preparation courses as their extra-curricular subjects and even integrate them in their curricula, since the labor market is in need of professionals 
who have a high TOEIC score as a guarantee that they have good knowledge of English. (Anthony, 2003)

The next interviewee named Ajarn Nualsri, who has been teaching TOEIC courses for almost 3 years at the school, had some views on the TOEIC preparation courses somewhat different from those of Ajarn Supannee, the first interviewee. Being asked whether the 4-mat model or the communicative approach was suitable to teaching TOEIC courses, she reasoned, "I would prefer the 4-mat model to the new teaching style (teacher-centered) in teaching TOEIC courses, because the students can understand more subtle grammar points, and they can have a chance to discuss things as well as to write and think creatively together." Nonetheless, she is still content with the new teaching style, for the students can learn from a lot of questions extracted from different TOEIC preparation books, which are similar to those questions in a real TOEIC examination. Also, the new teaching style to her was not time-consuming. Interestingly, she then revealed a negative point of teaching the courses that getting the students to listen to conversations and talks on the CDs made her often frustrated due to the students' lack of understanding and interest. Towards the end of the interview, the teacher proposed that there should be a compromise or a balance between the 4-mat communicative model and the teachercentered style in teaching TOEIC preparation courses, in order to alleviate the tremendous pressure being put on both the teachers and the students (Wilhelm \& Pei, 2008). In agreement with the first teacher's prediction, this teacher hoped that other schools, especially business and vocational ones, will have some TOEIC 
preparation courses to serve the needs of entrepreneurs and international businesses in the countries.

The last teacher whom I interviewed was Ajarn Panomwan, who was one of the first and most experienced TOEIC teachers in the school. In the interview, she remarked, "We have changed our teaching style in order to be compatible with the real TOEIC test." At this point, she explained that using the teacher-centered style of teaching in teaching TOEIC courses was more effective and faster. As an effect of the TOEIC test, she had to find a lot of TOEIC questions, apart from those in the studysheets, to get the students to be familiar with. However, she revealed, "This change from using the 4-mat model to using the teacher-centered teaching style has put on lot pressure. We are pressured the most when the slow students are ignorant to raising their TOEIC scores because of their bad attitudes towards learning the courses"(Newfileds, 2005). Moreover, even though she did not have to emphasize on teaching the students how to write and speak English, she sometimes felt rather guilty for not doing so. As a result, she suggested that in the near future the two skills, namely writing and speaking, should be included in the examination, and other business schools would have to integrate TOEIC courses in their curriculum.

After having interviewed the teachers to get more washback effects of the TOEIC examination on the teachers, I decided to interview some of the school's TOEIC students who have so far studied a number of TOEIC courses. Using the interview form with 11 questions, I conducted one-to-one 30-minute interviews with 3 TOEIC students of Sukhothai Business School to gain an opinion and suggestions 
on TOEIC courses and also find positive and negative effects of TOEIC on their learning and test-taking.

\section{Interviews of Students to Find Washback Effects}

The first student whom I interviewed was Oradee, who is a second-year diploma English-major student of Sukhothai Business School and also the current president of student committee. She has been studying 4 TOEIC courses at the school, and recently she has become the first student who obtained a score of 665 in the school's TOEIC mock examination at the end of academic year 2007. In the interview, she explained, "I knew that I had to take the mock TOEIC test at the end of the last academic year. It made me very nervous and was afraid that I wouldn't pass the test. So I decided to buy a few TOEIC preparation books at the bookstores in Bangkok and studied many sample tests in the books" (See, Ying, 2003). Furthermore, she admitted that studying TOEIC under great pressure had made her so tired and stressed out; however, it was really worth her effort and time. It was evident that she liked the TOEIC courses that she had been studying knowing that getting a high score would be her passport to her future career. Nevertheless, she felt a bit sad about studying TOEIC courses with the new teaching style and commented, "Unlike what happened in the first year of studying TOEIC, I don't have much time to interact with my friends in class now. There is no time for making a fun group presentation in class." She further revealed that reading was her favorite section, especially parts 6 and 7, for she could just read the questions and easily search for the answers within the texts, without thinking much. When asked whether the courses could provide communicative competence, she said, “I don't think having a 
high TOEIC score can guarantee that one can speak English or write in English better, because it doesn't include any speaking or writing elements" (See, Chapman, 2003). In her prediction of future of TOEIC courses in Bangkok, she said, "Other business and vocational schools will follow us soon, because TOEIC preparation courses are useful to fresh graduates who would like to work at an international company."

In the interview with the second diploma English-major student named Namfah, who has been studying 4 courses as well and recently got a high score in the TOEIC mock test, it was found that her English grammar had improved dramatically from doing many sample tests, especially Part 5 of TOEIC. Additionally, practicing Parts 1-2 (Photo Description and Questions \& Responses) helped her communicate in English better than before. Being asked about the usefulness of the old learning style (using the 4-mat model) for studying TOEIC courses, she replied, "I think it was a waste of time to learn TOEIC that way, because a lot of time was spent on the learning activities and grammar points, not on sample TOEIC questions." She added, "The new study-sheets which have been divided into 6 units concentrating on 6 different grammar points with relevant sample TOEIC questions are interesting and straight to the point (not confusing), because these things we will see in a real TOEIC test." In contrast with the interview with the first student Oradee, Namfah did not believe that other business schools in the country will adopt TOEIC courses into their syllabuses. Instead, they would concentrate on more business courses which can help the students to survive at the workplace. Moreover, she commented, "A TOEIC score is not quite reliable, because there can 
be limitations when it comes to doing a "real examination" (to be taken before graduation), such as time-constraint, technological barriers (bad sound system in the lab), and an overload of grammar and vocabulary (See also, Lauer, 2006). It is good for those who are fast test-takers." In other words, she thought that a TOEIC preparation course was all a matter of test-taking skills.

The last person whom I had an interview with was an anonymous third-year certificate English-major student of Sukhothai Business School, who has been studying for 5 TOEIC courses but scored not quite well in her most recent mock TOEIC examination. In the interview, she promptly complained, "Everything about TOEIC is too difficult to learn, because there are too many questions about grammar in the reading section and the questions in the listening section are read too fast!" She further revealed that she is not happy with the way the teacher is teaching her with new style of teaching. She revealed, "I was happy with the old learning style where I could participate in many group activities and see a lot of interesting and provocative teaching materials used by the teacher. The new way of learning is very boring, because the teacher simply gives us 20-30 TOEIC questions to do in each class!" However, she still believed that if she had gotten a high score, she could have used it for applying for a good job. In addition, she will try to find a book on TOEIC preparation, for fear that she might fail in the real examination to be taken before graduating from the school. Finally, she forecasted that some other vocational schools would include TOEIC courses in their curricula, so that their students would get a high TOEIC score which could be used for applying for a good job. However, 
she added, "When they teach the courses, make sure there is a balance between the teacher's role and the students' role in class" (see also, Wilhelm \& Pei, 2008).

\section{Conclusion}

According to all the interviews with the teachers and students above, it can be concluded that there are both positive and negative effects of the TOEIC preparation courses on the TOEIC teachers and learners of Sukhothai Business School in Bangkok, Thailand. In order to increase positive washback effects and at the same time reduce the negative washback effects of TOEIC on the learners, there should be practical measures used by the TOEIC teachers appropriately, such as creating a balance between the teaching-centered approach and the child-centered approach, including pair work and group activities in teaching plans, pointing out the benefits of getting a high TOEIC score, or giving positive reinforcement to the students. Likewise, there should be effective and proper strategies and techniques for increasing positive washback effects and decreasing negative washback effects of TOEIC on the TOEIC teachers at Sukhothai Business School. For example, the teachers should be allowed to use the 4-mat model (communicative approach) at certain points of a class by getting them to do some pair work or group work with some writing and speaking elements incorporating the required grammar points, so that the class will be more interesting, fun, and not too stressful to both the teacher and students.

In the near future, other business and vocational schools in Bangkok and other provinces are likely to adopt TOEIC preparation courses as their extracurricular subjects and even integrate them with their curricula, because at the 
moment international companies and organizations are seeking graduates with required qualifications, including a high TOEIC score. Importantly, these schools will need to plan for how to teach TOEIC courses effectively in order that the students will get a high score. In addition, they will take into consideration the issue of washback effects of TOEIC both on the teachers and learners of TOEIC preparation courses.

Due to the fact that all of the participants in this present study were teachers and students of Sukhothai Business School and the duration of the study was quite limited, there should be further research on both positive and negative washback effects on general Thai TOEIC teachers and learners at other institutions soon.

\section{References}

Alderson, J., Charles \& Hamp-Lyons, L. (1996). TOEFL preparation courses: a study of washback. Language Testing 13 (3), 280-297.

Anthony, L. (2003). Integrating the TOEIC into the university English curriculum. Proceedings of JACET 42th Annual Convention, 149-149.

Chapman, M. (2003). TOEIC: Tried but undertested. Shiken: JALT Testing $\mathcal{E}$ Evaluation SIG Newsletter, 7 (3), p 2-5.

Green, A. (2007). Washback to learning outcomes: a comparative study of IELTS preparation and university pre-sessional language courses. Assessment in Education: Principles, Policy \& Practice, 14 (1).

Larsen-Freeman, D. (2000). Techniques and principles in language teaching (2nd ed.). London: Oxford Press. 
Lauer, J. (2006). The grammar-vocabulary abilities of Japanese university freshmen on the TOEIC. Retrieved on December 23, 2008, from http://ir.lib.hiroshimau.ac.jp/metadb/up/kiyo/AA11424332/h-gaikokugokenkyu9_53.pdf

Nall, T. (2003). TOEIC: A Discussion and Analysis. ELT Two Cents Cafe. Retrieved on December 9, 2008, from http:/ / www.geocities.com/twocentseltcafe/teach/toeic.html Robb, T., \& Ercanbrack, J. (1999). An overview [Abstract]. A Study of the Effect of Direct Test Preparation on the TOEIC Scores of Japanese University Students. Retrieved December 19, 2008, from http:/ / eric.ed.gov/ERICWebPortal/custom/

Scott, H. V. (1994). A serious look at the 4 MAT model. Education Resources Information Center (ERIC).

Wilhelm, K. H. \& Pei, B. C. (2008). University teachers and students' perceptions of ELT methodologies and their effectiveness. GEMA Online Journal of Language Studies 79 Vol. 8(2).

Ying, Z. (2003). An overview [Abstract]. Washback on Chinese learners: An impact study of the College English Test Band 4, Retrieved December 18, 2008, from http://www.iaea2008.cambridgeassessment.org.uk/ca/digitalAssets/ 164766_Zhan.pdf 